\title{
The Domestic Decisionmaking Process and Its Implications for International Commitments: American Beef in Korea
}

\author{
Hi-Taek Shin ${ }^{\dagger}$
}

\section{INTRODUCTION}

As the global economic crisis deepens, even the governments of major market economies are susceptible to domestic political pressures to adopt protectionist trade policies. In a speech given at the University of California, Berkeley in October 2008, Pascal Lamy, the Director-General of the World Trade Organization (WTO), stated that restoring citizens' confidence in international trade requires governments to ensure that sound domestic policies are in place. The domestic decisionmaking process must be capable of synthesizing diverse and occasionally conflicting points of view into solid domestic policies. Issues related to free trade are no longer centered on the loss of jobs and the undermining of domestic industries. Contemporary issues include public health and safety concerns that affect the broader community, not merely a subset of the population. Now that ordinary citizens and civil society groups are able to disseminate and receive information instantly through the internet, they are increasingly capable of shaping international trade issues and influencing public opinions and government policy. A sound domestic decisionmaking process relating to international trade must consider all of these factors, adding to the complexity of the balancing process.

Balancing interests among domestic constituents through an orderly political or administrative process is a challenge for both mature democratic societies and rapidly democratizing countries like Korea. If the domestic decisionmaking process relating to international treaties does not produce policies that are substantively and procedurally sound, the rule of law may be undermined. This could, as a result, undercut the ability of the government to negotiate, conclude, and execute international agreements.

The controversy surrounding the resumption of importation of American beef into Korea in 2008 exemplifies the complexity of balancing competing

$\dagger \quad$ Professor of Law, Seoul National University School of Law. The author first encountered the New Haven School when he attended Professor Reisman's class in 1982 as an LL.M. student at the Yale Law School. As a law student educated in a continental civil law system in Korea, where military elites and technocrats dominated the decisionmaking process from the early 1960s until 1987, the significance of the New Haven jurisprudence was difficult to appreciate at the time. As Korea progressed into a democratic society, however, the necessity of improving the sociopolitical process of authoritative decisionmaking became apparent and, in this context, the relevance of the New Haven School to Korea became clear. This Essay endeavors to apply the policy-oriented perspective of the New Haven School to one episode involving the importation of U.S. beef into Korea. The author thanks Julie A. Kim and Yun Bak Chung for their invaluable assistance in developing this Essay. 
interests in a country that is in transition to full democratic maturity. While an elaborate domestic decisionmaking framework is detailed in the Korean Constitution and national laws, in practice, the decisionmaking process is not always orderly when it involves economically, socially, and politically sensitive issues. But when the domestic balancing process fails, it has serious repercussions for international law. In light of the current global economic crisis and countries' growing inclinations towards protectionist trade policies, Korea's experience with the U.S. beef import issue may be repeated in other parts of the world. ${ }^{1}$ Particularly under these conditions, a sound domestic decisionmaking process becomes all the more critical to the viability of our international trading system.

This Essay reviews the Korean Administrative Procedure Act (KAPA) ${ }^{2}$ and its implications for the Korea-U.S. Beef Import Agreement as set forth in the Agreed Minutes (Agreement) ${ }^{3}$ to analyze the legal status of the Agreement under international law and to understand whether Korea's commitment to implement the Agreement is unconditional or subject to KAPA's domestic procedural requirement for public notice and comment. I conclude that the Agreement is valid under international law, but that its implementation is subject to KAPA based on the Agreement's explicit recognition of the KAPA requirement. Consequently, the implementation of the Agreement and the domestic balancing process required by KAPA are bridged by the recognition of KAPA in the Agreement itself.

\section{FACTUAL BACKGROUND}

Korea was the third largest export market for American beef until the Korean government banned U.S. beef imports when mad cow disease was first reported in the United States in December 2003. Resumption of the importation of U.S. beef has since emerged as a delicate trade issue. When Korea expressed its intent to negotiate a free trade agreement with the United States in 2005, certain members of the U.S. government made clear that their support of the free trade agreement depended on whether Korea reopens the market to imported U.S. beef. ${ }^{4}$ However, trade officials in Korea cautiously maintained that the importation of American beef was not a prerequisite to beginning the two countries' free trade agreement negotiation ${ }^{5}$ out of concern

1. E.g., Malaysians Protest Against Free Trade Talks with U.S., THIRD WORLD NETWORK, June 13, 2006, http://www.twnside.org.sg/title2/FTAs/info.service/fta.info.service013.htm. Other examples include Thailand and Malaysia's free trade agreements with the United States. Both countries' citizens emphasized health concerns by protesting against the banning of generic medicines.

2. Heng Jung Jul Cha Bup [Administrative Procedure Act (KAPA)], Act No. 5241, Dec. 31, 1996, amended by Act. No. 8852, Feb. 29, 2008 (S. Korea) [hereinafter Korean Administrative Procedure Act].

3. Agreed Minutes of the Korea-United States Consultation on Beef, U.S.-S. Korea, Apr. 18, 2008 (on file with author) [hereinafter Agreed Minutes]

4. See, e.g., Press Release, Rob Portman, U.S. Trade Representative, Press Conference at Closing of APEC Trade Minister's Meeting (June 3, 2005), http://www.ustr.gov/Document_Library/ Transcripts/2005/June/USTR_Portman_Press_Conference_at_Closing_of_APEC_Trade_Ministers_ Meeting.html.

5. Press Release, Ministry for Food, Agric., Forestry, and Fisheries, Korea, U.S. May Compromise over Beef Trade Row, Seoul's Ambassador Says (Feb. 11, 2007), http://english.mifaff 
that the Korean public would misunderstand the government's action as exchanging the people's health for the free trade agreement.

Shortly before both governments announced their intention to negotiate a free trade agreement in February 2006, the Korean government agreed to a partial lifting of the import ban on U.S. beef; Korea would allow the importation of boneless U.S. beef derived from cattle less than thirty months old (believed to be at less risk of mad cow disease). Pursuant to relevant Korean law, ${ }^{6}$ the terms and conditions of the partial import agreement were implemented by the Ministry of Agriculture in the form of a ministry "notification" (gosi in Korean). KAPA requires that before any ministry introduces and implements a notification, it must publish the highlights of the notification to the general public and solicit public comments. ${ }^{7}$ The Ministry of Agriculture followed the procedure under KAPA and the notification took effect in March 2006 (2006 Notification). ${ }^{8}$ Importation of American beef resumed, but shortly afterwards the Korean government again prohibited the importation of U.S. beef when pieces of bones were found in it. The Agriculture Ministry held that the inclusion of bone chips in the imported beef was a violation of the 2006 Notification. While U.S. exporters requested reasonable bone chip tolerance for future shipments, the Korean government maintained a strict stance. The Trade Minister stated that "the beef issue should not be viewed as [a] market access issue, but a national health issue." When bone chips were again found in a shipment to Korea, Korean government placed a total ban on the importation of U.S. beef in October 2007 in response to mounting public concerns over the repeated violations of the 2006 Notification by some U.S. beef exporters.

Meanwhile, two important developments occurred. First, following ten months of intense negotiations, Korea and the United States signed the KoreaU.S. Free Trade Agreement (KORUS FTA) in June $2007 .{ }^{10}$ For the United States, KORUS FTA is the first free trade agreement with a major Asian economy. For Korea, it is the country's largest free trade agreement. As a next step, both governments must seek approval of the KORUS FTA from their respective legislatures.

Second, in May 2007, the World Organization for Animal Health (OIE) identified the United States as a "controlled risk" country for Bovine Spongiform Encephalopathy. ${ }^{11}$ Based on the WTO Agreement on Sanitary and

go.kr/USR/BORD0201/m_380/DTL.jsp?id=B20201000\&mode=view\&idx=10903.

6. Act on the Prevention of Contagious Animal Diseases, amended by Act. No. 7434, Mar. 31,2005 (S. Korea).

7. Korean Administrative Procedure Act, supra note 2, arts. 41-42.

8. Nong Rim Bu Go Si [Ministry of Agriculture and Forestry Notification], Mi Kook San Swe Go Gi Soo Ip Wie Seng Jo Gun [Health Conditions for Importing U.S. Beef], No. 2006-15 (Mar. 6, 2006) (on file with author).

9. KOREA INST. FOR INT'L ECON. POLICY, FEASIBILITY AND ECONOMIC EFFECTS OF KOREAU.S. FTA 62 n.72 (Dec. 30, 2005) (internal quotation marks omitted), available at http://www.kiep.go.kr/common/board_file_down.asp?131932.

10. Press Release, Office of the U.S. Trade Representative, United States and the Republic of Korea Sign Landmark Free Trade Agreement (June 30, 2007), http://ustr.gov/Document_Library/Press _Releases/2007/June/United_States_the_Republic_of_Korea_Sign_Lmark_Free_Trade_Agreement. html.

11. Press Release, U.S. Dep't of Agric., Statement by Secretary Mike Johanns Regarding 
Phytosanitary Measures, ${ }^{12}$ the U.S. government demanded that Korea conform to the WTO rules by eliminating the import ban. In particular, the United States stipulated that Korea should expand the age limit of the cattle, allow boned meat, and relax the inspection standard so that minute issues like small bone chips do not trigger a suspension of imported U.S. beef. Influential American politicians strongly signaled that they would not support the KORUS FTA in Congress unless and until Korea resolves the U.S. beef import issue. One day before the newly elected President Lee was scheduled to meet President Bush in April 2008, the Korean Agriculture Ministry announced that it had agreed with the United States to lift the import ban on U.S. beef. As the implementation of the Agreement required an amendment to the 2006 Notification, the Ministry published the major contents of the new Beef Import Agreement and sought public opinion pursuant to KAPA.

When the contents of the Agreement became known to the Korean public, journalists, and civil society groups, they requested to know the basis for this seemingly sudden shift in policy and whether the government had taken due consideration of the citizens' health and safety when it agreed to expand the scope of U.S. beef shipped to Korea and to relax inspection standards. ${ }^{13}$ In response, the government explained that the U.S. beef to be imported was the same safe beef that Americans consumed daily and that Korea had to accept the OIE international standard unless objective scientific grounds justified deviation from the OIE guidelines. Special hearings were held at the National Assembly, but failed to ease the public's concerns. Soon mass demonstrations took place in the streets of Seoul. Protestors demanded renegotiation of the Agreement to reduce the scope of imported U.S. beef and to restore Korea's full right to inspection. Opposition party politicians and leaders of NGOs critical of the administration joined the crowds.

The government maintained that renegotiation was not legally possible and that it would hurt Korea's international credibility. In light of the domestic reaction, however, the Minister of Agriculture postponed finalization of the amended notification. The Minister explained that the delay was due to the fact that the public submitted more than three hundred opinions that the Ministry needed time to review. When it became evident that the Korean government was no longer in a position to ignore public opinion, it asked the United States for additional consultations. On June 25, 2008, the Korean government succeeded in securing additional safeguards in the form of a "private sector initiative." The letter, which was jointly signed by then-U.S. Trade Representative Susan Schwab and Secretary of Agriculture Edward Schafer, confirms that Korea will import U.S. beef from cattle less than thirty

U.S. Classification by OIE (May 22, 2007), http://www.usda.gov/wps/portal?contentidonly=true\& contentid $=2007 / 05 / 0149 . \mathrm{xml}$.

12. Agreement on the Application of Sanitary and Phytosanitary Measures art. 2, para. 2, Apr. 15, 1994, Final Act Embodying the Results of the Uruguay Round of Multilateral Trade Negotiations, Annex 1A, Legal Instruments-Results of the Uruguay Round, available at http://www.wto.org/english/docs_e/legal_e/17-tbt.pdf.

13. E.g., Thousands Protest U.S. Beef in S. Korea, CBS NEWS, May 31, 2008, http://www.cbsnews.com/stories/2008/05/31/world/main4142669.shtml. 
months of age until Korean consumer confidence improves. ${ }^{14}$ The Agriculture Ministry published the amended notification that went into effect from June $26,2008 .^{15}$

\section{LEgAL ANALYSIS OF THE AgREEMENT WITH THE UNITED STATES}

In responding to the demands for renegotiation of the Korea-U.S. Beef Import Agreement, the options available to the Korean government depend on (1) what the legal status of the Agreement is under international law, and (2) whether Korea's commitment to implement the Agreement is unconditional or subject to KAPA's procedures for public notice and comment.

Let us briefly review the details of the Agreement. On April 18, 2008, the Deputy Minister of the Korean Ministry of Food, Agriculture, Forestry and Fisheries and the Deputy Under Secretary of the U.S. Department of Agriculture signed a five-page document entitled the Agreed Minutes of the Korea-United States Consultation on Beef. ${ }^{16}$ The Agreement states that the two delegations reached agreement on a new protocol for the importation of beef and beef products from the United States into Korea, and a copy of the agreed protocol is attached to the Agreement (Import Protocol).

With respect to the first question, opinions are split among Korean legal scholars. Some legal scholars and jurists critical of the current Korean government argue that the Agreement is not a valid international agreement because it is simply a record of a "consultation," not a binding agreement. ${ }^{17}$ Others argue that the substantive issues dealt with in the Agreement significantly affect the health and safety of Korean citizens, and therefore should not have been delegated to the ministry notification level. ${ }^{18}$ The argument follows that because the Agreement was signed by the Deputy Minister without approval from the National Assembly or, at least by the state cabinet, the Agreement has no legal status in Korea. ${ }^{19}$

However, the Korean government has rejected these arguments, designating the Agreement to be a binding international agreement duly signed by representatives of both countries. The Minister of Trade stated that seeking renegotiation of a binding international agreement was not legally possible, but proposed that the government would seek additional

14. Letter from Susan Schwab, U.S. Trade Representative \& Edward Schafer, U.S. Sec'y of Agric., to Jong Hoon Kim, S. Korea Minister for Trade \& Woon Chun Chung, Minister for Food, Agric., Forestry and Fisheries (June 25, 2008), available at http:/www.ustr.gov/assets/Document_ Library/Fact_Sheets/2008/asset_upload_file470_14958.pdf.

15. Nong Rim Soo San Sik Poom Bu Go Si [Ministry of Food, Agriculture, Forestry \& Fisheries Notification], Mi Kook San Swe Go Gi Soo Ip Wie Seng Jo Gun [Health Conditions for Importing U.S. Beef], No. 2008-15 (June 26, 2008) (on file with author).

16. Agreed Minutes, supra note 3.

17. Yang Gu Kang, Gook Ga Hyup Sang? Jong Hyun Kim Yi Dae Tong Ryung Gua Kook Min Eul Sok Yi Ko It Da [Additional Negotiation? Jong Hyun Kim Is Deceiving the President and the People], Pressian, June 17, 2008, http://www.pressian.com/article/article.asp?article_num= 60080616213647 (interviewing the former Korean Minister of Agriculture).

18. Young Sok Kim, Han Mi Swe Go Gi Soo Ip Hab Eui Eui Kook Je Bub Juk Gum To [A Review of the Korea-U.S. Beef Agreement from an International Law Perspective], 15 SEOUL KooK JE BUB YUN Goo [SEOUL INT'L L.J.] 29, 38-42 (2008) (S. Korea).

19. Id. at 41-44. 
consultations to address the public health and safety concerns with the U.S. government.

Considering the parties' intentions as expressed in the wording of the Agreement, and the signatures affixed to the Agreement, as well as the parties' history of dealing with the same issue in 2006 (which led to the 2006 Notification), it is hardly convincing to argue that the Agreement is not a binding agreement governed by international law.

With respect to the second question, it is important to point out that the Agreement makes explicit references to both the Korean and the U.S. administrative procedure laws. The reference to the administrative procedure laws of both countries indicates that the representatives of each delegation were fully cognizant of the fact that the implementation of the Agreement would be subject to each state party's domestic processes as required by their respective administrative procedure laws. This explicit reference to a domestic rulemaking procedure raises the complex issue of how the internal procedural requirement of KAPA (that public opinions be taken into consideration in the government's decisionmaking process) can be integrated at the international decisionmaking level.

Under Korean law, in order to implement the Agreement, the Agriculture Ministry has to amend the 2006 Notification to reflect the terms and conditions set forth in the Import Protocol. The amendment of the 2006 Notification is subject to the KAPA procedure. ${ }^{20}$ The purpose of the public comment process under KAPA is to guarantee public access to and participation in the administrative rulemaking process, thus giving the people the right to be publicly critical of a particular administrative regulation before it becomes effective. KAPA states that the public comment period shall be for at least twenty days. It also provides that any person has the right to offer his or her opinion on the regulation and the government must treat such opinion respectfully. If the regulation in question raises a diverse group of issues, then the government may hold public hearings to facilitate the democratic process. However, KAPA does not contain detailed guidelines on the standard of treatment for the submitted public opinion.

Without clarifying the extent of Korea's obligations, that is, whether Korea's promise to implement the Agreement is unconditional or contingent upon KAPA's procedural requirements, the Korean government maintained that the public opinions opposing the Import Protocol failed to present an objective scientific basis to support their position.

According to Articles 26 and 27 of the Vienna Convention on the Law of Treaties, a treaty must be performed in good faith and a party's internal law cannot be invoked as an excuse for nonperformance of a treaty. ${ }^{21}$ If KAPA were not specifically mentioned in the Agreement, then invoking KAPA would not be justifiable under Article 27 of the Vienna Convention. However, in this case, the Agreement states the following:

20. Korean Administrative Procedure Act, supra note 2, arts. 41-45.

21. Vienna Convention on the Law of Treaties arts. 26-27, May 23, 1969, 1155 U.N.T.S. 331, 8 I.L.M. 679. 
Korea stated that no later than April 22, 2008, the Ministry for Food, Agriculture, Forestry and Fisheries will publish for public comment the import health requirements for beef and beef products contained in the protocol. As soon as the public comment period required by Korea's Administrative Procedures Act closes ( 20 days after publication), the protocol will be published as a final regulation. ${ }^{22}$

While the language is somewhat vague, a strong argument can be made that Korea's agreement to implement is qualified by the reference to KAPA, which requires a public notice and opinion-seeking procedure. The Korean government must "in good faith" 23 perform what it has agreed to, but it reserved the right to subject the Agreement to KAPA's requirement.

Several important considerations support this argument. First, when Korea agreed to partially resume importation of U.S. beef in 2006 , the Ministry of Agriculture abided by the same KAPA procedure. The U.S. delegations were therefore aware of the KAPA requirement. Second, the chief Korean negotiator was a deputy-minister-level officer who is required by law to act in accordance with KAPA, and he did not have the authority to waive the KAPA requirements during the negotiation process with the United States. Furthermore, the Agreement explicitly states that the U.S. government will conduct its obligations "within the parameters of the U.S. Administrative Procedures [sic] Act." ${ }^{24}$ Thus, it is logical that the Korean government is similarly obligated to implement the Agreement subject to the requirements of KAPA.

Certainly, Korea must perform the Agreement in good faith and refrain from taking any action that defeats its object and purpose. If the Ministry finds, however, in the course of complying with KAPA, that the public raised substantial health concerns relating to the Agreement, the Minister must take appropriate measures to address the concerns, for instance, holding public hearings or organizing a special task force to examine the scientific basis of the issues. If, through this process, scientific evidence that supports public objection to the implementation of the Agreement arises, then Korea may decide not to implement the Agreement as originally agreed and may demand renegotiation to the extent justified by the objective scientific evidence. Whether the United States accepts such demand for renegotiation or not is a decision to be made by the U.S. government. What is important is that Korea's failure to implement the Agreement should not be viewed as a breach of the Agreement as long as Korea acted in good faith.

Although the Korean government deliberately created the appearance that it would not seek renegotiation, in reality, the additional consultations preceding the finalization of the amended notification on the American beef Import Protocol were in substance supportive of the interpretation that Korea's commitment under the Agreement was subject to the KAPA requirement. In hindsight, if the Korean government had taken the position from the outset that the Agreement was subject to the KAPA procedure, thus faithfully following the KAPA procedure and giving more respect to public

24. Agreed Minutes, supra note 3, at 2, 3; see also id. at 4 (using similar language). 
opinion in the consensus-building process, it might have been more successful in having the Beef Import Agreement implemented in an orderly manner. The public debate would have been focused on verifying whether there was an objective scientific basis for the health and safety concerns raised over American beef rather than being a highly politicized spectacle filled with polarizing rhetoric and physical confrontation between the so-called conservatives and progressives.

\section{CONCLUSION}

Korea faces the critical challenge of upgrading its domestic decisionmaking processes relating to international treatymaking. Until the late 1980 s, policymaking in Korea was monopolized by a few political elites. Yet with rapid democratization and an increasingly active civil society, demands for meaningful public participation in Korea's decisionmaking process are growing stronger. Ordinary citizens want their voices to be reflected in the country's treaty decisionmaking process, especially on issues that affect their health, safety, and living environments. Paradoxically, the position the Korean government took in the U.S. beef controversy in order to maintain its international credibility ultimately hurt the government's domestic credibility, which in turn weakened its ability to perform its international commitments.

The U.S. beef controversy highlights the need for trade negotiators to carefully consider the domestic decisionmaking process of their counterparties when negotiating international agreements. It also teaches us the increasingly important role that domestic policymaking processes play, especially in our currently charged global economic environment, in maintaining the viability of our international legal system. 